\title{
Influence of Season and Housing System on Growth Performance, Blood Metabolites and Physiological Responses of Growing Friesian Calves
}

\author{
Samir A. Nagadi ${ }^{1}$, Mahmoud S. Sayah ${ }^{1}$ and Samir Z. El-Zarkouny ${ }^{1,2}$ \\ ${ }^{1}$ Department of Arid Land Agriculture, Faculty of Meteorology, Environment and Arid Land \\ Agriculture, King Abdulaziz University, Jeddah, Saudi Arabia and ${ }^{2}$ Department of Animal and \\ Fish Production, Faculty of Agriculture, Alexandria University, Alexandria 21545, Egypt \\ mahmoud_sayah@yahoo.com
}

\begin{abstract}
Sixteen Friesian growing calves were used to study growth and physiological responses during winter, spring and summer under tie-stall and loose housing systems. Significant differences $(\mathrm{P}<0.01)$ were recorded between the two systems for body weight gain $(96.38 \mathrm{vs.}$ $82.32 \mathrm{~kg})$, daily weight gain $(1.02 \mathrm{vs} .0 .92 \mathrm{~kg})$, water intake $(59.70 \mathrm{vs} .77 .51 \mathrm{ml} / \mathrm{kg})$, rectal temperature $\left(38.6\right.$ vs. $\left.38.9^{\circ} \mathrm{C}\right)$ and respiration rate $(41.7$ vs. 48.7 resp./min. $)$ in favor of tie-stall. However, DMI, ST and blood metabolites showed insignificant differences. Animals showed better growth performance in tie-stall than loose barn. Housing systems affected growth performance and body reaction, but it did not act blood parameters. In the meantime, seasons exerted significant effects for all parameters in in favor of winter.
\end{abstract}

Keywords: Tie-stall, Loose housing, Friesian, Growth, Blood metabolites.

\section{Introduction}

Proper housing with good management enable the breeder to grow healthier and fast growing calves for replacement or marketing with minimal animal loss. Pusillo et al. (1991) reported that housing systems had a significant effect on growth rates of calves, it significantly influenced cattle feedlot performance without influencing body composition. The major requirements of animal housing practice can be translated into specifications for climate, space, allowances, ventilation and shelter or pen design (Lawrence, 1994). Prawl et al. (1998) found that steers with less space had lower dry matter intake but their gain was similar to steers fed in larger pens. However, other investigators found insignificant effect of housing design on growth rates such as; body weight (BW), daily gain (DG), carcass weight, or dressing percentage. (Terosky et al., 1997 and Chua et al., 2002). This may due to different housing conditions investigated by the authors.

Plenty of authors studied the physiological reactions of different cattle breeds to natural environmental conditions under different housing systems. There was a great deal of agreement between their results. Cattle body reactions were related to temperature humidity index (THI) (Castaneda et al., 2004). Body reaction values increased linearly with increasing air temperature. The values of rectal temperature (RT), skin temperature (ST) and respiration rate (RR) showed high correlations with air temperatures (Sayah, 2005; Ashour et al., 2007 and Cardoso et al., 2015). Outside the comfort zone, the animal experiences stress to remain 
homoeothermic (Nardone et al., 2006). Changes in blood metabolites levels due to exposure of animals to air temperature have been studied by several (Abdel-Samee et al., 1996; Sayah, 2005 and Ashour et al., 2007 and Sayah et al., 2015). In addition, changes of housing system can alter the animal performance (Terosky et al., 1997; Sayah, 2005 and Sayah et al., 2015). The main objectives of this study were to evaluate the effects of housing system and seasonal variation on growth performance and physiological responses of growing Friesian calves kept under two different housing systems (tie-stall and loose barns) in winter, spring and summer seasons.

\section{Materials and Methods}

\subsection{Animals and Management}

A total of 16 healthy male growing Friesian calves at 6-7 months of age and averaged $123 \pm 8.2 \mathrm{~kg}$ live body weight were selected and divided into two equal groups $(n=8)$ according to their age and body weight. The first group was housed in a loose barn while the second group $(n=8)$ was housed in a tie-stall barn. Both groups were kept in a fully shaded semi-open barn under the same environmental conditions during three consecutive seasons (winter, spring and summer). The barn was $30 \mathrm{~m}$ length and $7.5 \mathrm{~m}$ width, which was roofed by an asbestos sheet at $3.5 \mathrm{~m}$ high on a concrete floor with proper drainage. The barn was divided into two equal parts, the first part contained eight loose animals (G1), and the second part contained the tethered animals (G2). The allocated space for each loose animal was $12 \mathrm{~m}^{2}$. The barn was surrounded by brick walls having wide (about $60 \%$ of the wall) ventilation openings.

The animals were offered a daily allowance of concentrate ration in accordance with NRC (1981) once daily in the morning then followed by fresh berseem (Trifolium
Alexandrinum) during winter and spring seasons or berseem hay during summer with rice straw ad libitum according to the farm routine. At the end of the test day, orts were weighed and recorded as a group feeding. Then, the dry matter intake (DMI) was calculated based on the dry matter percentage of every feedstuff intake in terms of $\mathrm{kg} / \mathrm{head} /$ day. In addition, relative DMI was calculated based on the metabolic body weight $(\mathrm{MBW})$ in $\left(\mathrm{W}^{0.75}\right)$ and tabulated as DMI $(\mathrm{g} / \mathrm{kg}$ MBW).

Fresh drinking water was offered in a measured water trough that were used to determine water consumed by animals in every test day. At the end of the test days, the absolute water intake of calves recorded based on the residual water after drinking, where it was subtracted from the offered water and estimated as litre/head/day. The relative water intake was calculated based on the metabolic body weight MBW in $\left(\mathrm{W}^{0.75}\right)$ and tabulated as $\mathrm{WI}(\mathrm{ml} / \mathrm{kg} \mathrm{MBW})$.

\subsection{Experimental Procedures}

The experimental procedures were carried out monthly for the two housing systems at the same day. Some physiological parameters were determined twice and others were taken once during the experimental day.

\subsection{Environmental Conditions and Physiological Parameters}

Air temperature $\left(\mathrm{AT},{ }^{\circ} \mathrm{C}\right)$ and relative humidity (RH, \%) were recorded twice daily at 08:00 and 14:00 h. using alcohol thermometers and electronic thermo-hygrometer. The following equation was used to determine the temperature-humidity index (THI) as an indicator of adverse climatic conditions using the equation of Castaneda et al. (2004):

$\mathrm{THI}=(1.8 \times \mathrm{T}+32)-[(0.55-0.0055 \times \mathrm{RH})$ $\times(1.8 \times \mathrm{T}-26)]$, where: $\mathrm{T}$ is air temperature $\left({ }^{\circ} \mathrm{C}\right)$ and $\mathrm{RH}$ is the relative humidity $(\%)$. 


\subsection{Blood Compositions, Body Reactions and Body Weight Performance}

Blood samples were taken monthly from five animals in each group and same animals were reassigned for blood collection each time thereafter. Blood samples were centrifuged at $3000 \mathrm{rpm}$. for 15 minutes and harvested plasma samples were stored at $-20{ }^{\circ} \mathrm{C}$ for later analysis of hormones and blood metabolites. Plasma total protein $(\mathrm{TP}, \mathrm{g} / \mathrm{dl})$, albumin $(\mathrm{g} / \mathrm{dl})$, total lipids (TL, g/l) and glucose (mg/dl) concentrations were determined using commercial kits according to the procedures outlined by the manufacturers. Globulin concentration $(\mathrm{g} / \mathrm{dl})$ was calculated by subtraction of plasma albumin from plasma total protein. Plasma thyroxine hormone $\left(\mathrm{T}_{4}, \mu \mathrm{g} / \mathrm{dl}\right)$ was determined using Thyroxine (IM 1447) kits which were delivered from Immunotech SA, Marseille, France. Rectal temperature (RT, ${ }^{\circ} \mathrm{C}$ ) was recorded using a digital thermometer while the measurements were recorded to the nearest $0.1^{\circ} \mathrm{C}$. Skin temperature $\left(\mathrm{ST},{ }^{\circ} \mathrm{C}\right)$ was recorded using an infrared thermometer at the fore-flanks region. Respiration rate ( $\mathrm{RR}$, breaths /minute) was recorded by counting the flank's movements per 1-minute using stopwatch. Live body weight (LBW, kg) was recorded monthly in the morning before access to feed and water. In addition, metabolic body weight was calculated according to ( $\mathrm{W}^{0.75}$ ). Moreover, daily weight gain (DWG) was calculated according to the body weight gain during the three seasons: winter for 83 days, spring for 91 days and summer for 108 days until the animals reached their final weight (370.3 $\mathrm{kg}$ for the loose animals and $412.3 \mathrm{~kg}$ for the tied animals as averages). The numbers of observation were obtained from 24 readings for each housing system for every season.

\subsection{Statistical Analysis}

The used experimental design is: 2factors experiment in completely randomized design (CRD). Statistical analyses of data was carried out using the software package of SAS (2002) with the following linear model: $\mathrm{Y}_{\mathrm{ijk}}=$ $\mu+\mathrm{H}_{\mathrm{i}}+\mathrm{S}_{\mathrm{j}}+\mathrm{HS}_{\mathrm{ij}}+\mathrm{e}_{\mathrm{ijk}}$, where: $\mathrm{Y}_{\mathrm{ijk}}$ is the experimental unit (ijk) value; $\mu$ is the overall mean; $\mathrm{H}_{\mathrm{i}}$ is the effect of housing effect (two levels, i, 1 and 2); $S_{j}$ is the season effect (three seasons, $\mathrm{j}, 1,2$ and 3$),(\mathrm{HS})_{\mathrm{ij}}$ is the effect of the interaction between housing (i) and season (j) and $\mathrm{e}_{\mathrm{ijk}}$ is the experimental error effect. Probability $<0.01$ was used to declare significance and Least Significance Difference (LSD) was used to separate means.

\section{Results and Discussion}

\subsection{Environmental Conditions}

The results in Fig. 1 showed that there were great seasonal and diurnal differences in climatic conditions. According to Castaneda et al. (2004), who stated that the upper critical THI for Holstein-Friesian cattle is 72, the Friesian growing calves were suffering from heat stress in summer (75.2 and 81.3, which reflected severely on the growing performance. Segnalini et al. (2013) indicated that the Mediterranean basin is likely to undergo THI changes, which may aggravate the consequences of hot weather on animal welfare, performances, health and survival. The THI values in winter (54.7 and 66.9) showed that calves were in their comfort zone where no suffering from heat stress. Mader et al. (2006) stated that although knowledge of THI alone is beneficial in determining the potential for heat stress, wind speed and solar radiation adjustments to the THI would be more accurately assess animal discomfort.

\subsection{Growth Performance}

\subsubsection{Feed and water intakes}

Data in Table 1 showed that there were no significant differences between the effects of tie-stall and loose housing systems on DMI during the three seasons. However, there were 
significant seasonal differences $(P<0.01)$ on DMI in terms of $\mathrm{g} / \mathrm{kg}$ LBW. There was a negative relationship between DMI and AT. Summer had the lowest value (26.71g) compared with the other values in winter and spring (29.44g and $28.53 \mathrm{~g}$, respectively). This result is in agreement with Morrison (1983) who mentioned that livestock performance is affected by heat stress because an animal having difficulty in losing heat will decrease its heat production by lowering, feed intake. NRC (1981) reported that the increases in respiratory rate and water consumption as well as decreased rumen motility, all contribute towards reducing appetite and intake. West (2003) stated that increasing air temperature, temperature-humidity index and rising rectal temperature above critical thresholds are related with decreasing dry matter intake (DMI).

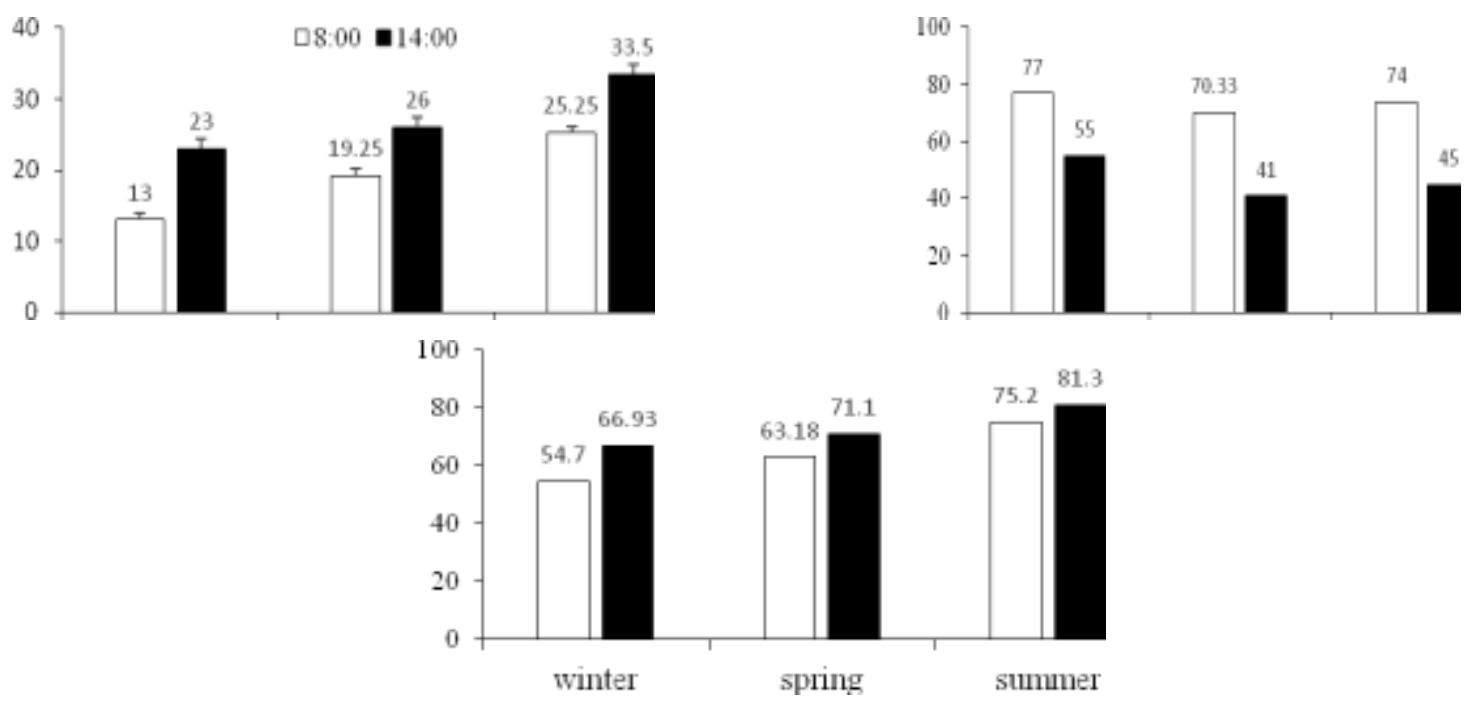

Fig. 1. Changes in air temperatures $\left(\mathrm{AT},{ }^{\circ} \mathrm{C}\right)$, relative humidity $(\mathrm{RH} \%)$ and temperature humidity index $(\mathrm{THI})$ at $08: 00$ and 14:00 hr. during winter, spring and summer seasons.

Table 1. Mean \pm SE of DMI, WI for young Friesian bulls kept in two different housing systems.

\begin{tabular}{|c|c|c|c|c|}
\hline \multirow{2}{*}{ Item/Housing types } & \multicolumn{3}{|c|}{ Season } & \multirow{2}{*}{ Overall } \\
\hline & Winter & Spring & Summer & \\
\hline \multicolumn{5}{|l|}{ DMI (g/kg LBW) } \\
\hline Tie-Stall & $29.52 \pm 0.4^{\mathrm{a}}$ & $28.13 \pm 0.3^{\mathrm{a}}$ & $26.29 \pm 0.2^{\mathrm{a}}$ & $27.98 \pm 0.3^{\mathrm{a}}$ \\
\hline Loose & $29.37 \pm 0.4^{\mathrm{a}}$ & $28.93 \pm 0.3^{\mathrm{a}}$ & $27.13 \pm 0.2^{\mathrm{a}}$ & $28.48 \pm 0.3^{\mathrm{a}}$ \\
\hline Overall & $29.44 \pm 0.3^{\mathrm{A}}$ & $28.53 \pm 0.2^{\mathrm{B}}$ & $26.71 \pm 0.2^{\mathrm{C}}$ & \\
\hline \multicolumn{5}{|l|}{ DMI (g/kg MBW) } \\
\hline Tie-Stall & $110.94 \pm 3.1^{\mathrm{a}}$ & $116.98 \pm 2.1^{\mathrm{a}}$ & $117.61 \pm 1.5^{\mathrm{a}}$ & $115.18 \pm 2.2^{\mathrm{a}}$ \\
\hline Loose & $107.77 \pm 3.1^{\mathrm{a}}$ & $117.82 \pm 2.1^{\mathrm{a}}$ & $119.54 \pm 1.5^{\mathrm{a}}$ & $115.04 \pm 2.2^{\mathrm{a}}$ \\
\hline Overall & $109.36 \pm 2.2^{\mathrm{B}}$ & $117.39 \pm 1.5^{\mathrm{A}}$ & $118.58 \pm 1.1^{\mathrm{A}}$ & \\
\hline \multicolumn{5}{|l|}{ WI (ml/kg LBW) } \\
\hline Tie-Stall & $49.79 \pm 1.7^{\mathrm{b}}$ & $60.24 \pm 1.6^{\mathrm{b}}$ & $69.08 \pm 1.4^{\mathrm{b}}$ & $59.70 \pm 1.6^{\mathrm{b}}$ \\
\hline Loose & $69.42 \pm 1.7^{\mathrm{a}}$ & $75.97 \pm 1.6^{\mathrm{a}}$ & $87.13 \pm 1.4^{\mathrm{a}}$ & $77.51 \pm 1.6^{\mathrm{a}}$ \\
\hline Overall & $59.61 \pm 1.2^{\mathrm{C}}$ & $68.11 \pm 1.1^{\mathrm{B}}$ & $78.11 \pm 1.0^{\mathrm{A}}$ & \\
\hline \multicolumn{5}{|l|}{$\mathrm{WI}(\mathrm{ml} / \mathrm{kg} \mathrm{MBW})$} \\
\hline Tie-Stall & $185.18 \pm 5.7^{b}$ & $251.13 \pm 6.2^{b}$ & $310.58 \pm 4.9^{b}$ & $248.96 \pm 5.6^{b}$ \\
\hline Loose & $254.23 \pm 5.7^{\mathrm{a}}$ & $309.27 \pm 6.2^{\mathrm{a}}$ & $381.03 \pm 4.9^{\mathrm{a}}$ & $314.84 \pm 5.6^{\mathrm{a}}$ \\
\hline Overall & $219.71 \pm 4.1^{\mathrm{C}}$ & $280.20 \pm 4.4^{\mathrm{B}}$ & $345.80 \pm 3.4^{\mathrm{A}}$ & \\
\hline
\end{tabular}


Furthermore, as far as DMI in terms of $\mathrm{g} / \mathrm{kg} \mathrm{MBW}$, the highest value was obtained in summer (118.58 g), while the lowest value was obtained in winter (109.36 g), spring had an approximate value (117.39 g) to summer. This means that animal under hot conditions needs more metabolic energy to increase its body weight one $\mathrm{kg}$ than animal under cold conditions. This result may due to the higher efficiency of feed utilization in winter than in summer.

Water intake results showed significant differences $(\mathrm{P}<0.01)$ between the two housing systems, where the loose animals consumed more water than tie-stall animals in terms of $\mathrm{ml} / \mathrm{kg} \mathrm{MBW}$ during winter, spring and summer (254.23 vs. $185.18,309.27$ vs. 251.13 and 381.03 vs. $310.58 \mathrm{ml} / \mathrm{kg} / \mathrm{MBW}$, respectively). The high values of $\mathrm{WI}$ in the loose system may due to the continuous movement of the animals. Moreover, there were seasonal variations in water consumption, where WI increased with increasing AT. Therefore, the need for water was seriously important, perhaps more than the need for other nutrients. El-Nouty (1996) stated that thermal stress causes a rise in core temperature in turn it activates heat loss mechanism via panting and sweating. This causes dramatic increase in water intake and urine output. Ashour et al. (2007) reported that water intake is affected by several factors such as: increase of dry matter intake, quality of the feed intake, level of $\mathrm{Na} \mathrm{Cl}$, however, climate is the most important factor affecting water intake, it has a dramatic effect on water consumption. The increase in WI in hot condition reflects the physiological role of water in counteracting heat stress by increasing water vaporization through skin and respiratory surface. The same trend was also observed in WI (ml/kg MBW).

\subsubsection{Growth rate}

The results in Table 2 showed that the BWG and DWG values were affected by the different housing systems. The tie-stall housing system had significantly higher $(P<0.01)$ values of BWG and DWG during the three seasons compared with the loose housing system under the same environmental conditions. This result is in agreement with Sayah (2005) who found that animals became adapted to its environment after exposing to severe climatic conditions. Bianca (1965) reported that the decreasing of the anabolism occurs, particularly, in the metabolizable energy for both maintenance and gain weight. On the contrary, Pusillo et al. (1991) indicated that open lot with overhead shelter caused higher average daily gain than feedlot cattle in open-front confinement building.

The results showed also seasonal effects for the three experimental seasons, the highest value of BWG was obtained in spring (101.63 $\mathrm{kg}$ ), while the lowest value was obtained in winter $(67.21 \mathrm{~kg})$. The values of DWG had the same trend of BWG. The BWG and DWG in summer decreased from $101.61 \mathrm{~kg}$ to 99.65 and from 1.12 to $0.92 \mathrm{~kg}$, respectively. This result is due to that animal in summer were under heat stress, which reflected on the growth performance and resulted in lower growth rate. This result is in agreement with Daader et al. (1989) who reported that the total body weight was decreased significantly in hot summer. Sakaguchi and Gaughan (2002) reported that exposing animals to high or low air temperature for a long time results in decreasing the daily weight gain. On the contrary, Muhamed et al. (1983) found that steers gained more $(P<0.05)$ in summer than in winter, especially for calves that reared outdoors.

The results showed also that the LBW values were affected significantly $(P<0.01)$ by the housing system. The tie-stall system had 
the highest values of LBW during the three seasons; winter, spring and summer compared with the loose system. The same trend was also observed in MBW.

\subsection{Physiological Parameters}

\subsubsection{Blood compositions and hormonal Responses}

In Table 3, the results showed that there were insignificant housing differences for all blood metabolites. As for total protein (TP), albumin and globulin showed that there were insignificant housing differences. However, summer season had lower values of TP, albumin and globulin concentrations compared with winter and spring. The results of total protein, albumin and globulin showed negative correlation coefficients with AT $(-0.14,-0.17$ and -0.20 , respectively). This result is in agreement with Shafie and Badreldin (1962) who found that the albumin content decreased in cattle $(-2.5 \%$ from $3.9 \mathrm{~g} / \mathrm{dl})$ when animals exposed directly to solar radiation. Lee et al. (1976) explained the phenomenon of increasing TP in low temperatures by globulin increase and primarily increase in the gamma fraction. Habeeb et al. (1992) stated that exposing farm animals to heat stress accompanied by biological changes including disturbance in protein and minerals metabolism. On the contrary, El-Masry and Marai (1991) showed a significant decline in plasma TP in Friesian calves in winter (4.8 $\mathrm{g} / \mathrm{dL})$ than in summer $(5.7 \mathrm{~g} / \mathrm{dL})$.

As for the results of total lipids (TL), winter had a lower value of TL $(2.82 \mathrm{~g} / \mathrm{L})$ compared with spring and summer (3.29 and $3.31 \mathrm{~g} / \mathrm{L}$, respectively). The results revealed that the low AT in winter had a suppressive effect on TL which has positive correlation coefficient with AT (0.26). This result is in agreement with the results of Collier et al. (1982) who reported that total lipids increased in hot weather as a result of increasing in ACTH and estrogens concentrations in heat stressed animals. Kandeal (2003) reported that such a phenomenon might be due to the increase in either body water content or utilization of fatty acids for energy production as a consequent of the decrease in glucose concentration. On the other hand, Ahmed (1990) reported higher concentrations of TL in Friesian calves during winter (361.3 $\mathrm{mg} / \mathrm{dl}$ ) than under the hot condition of summer (278.5 mg/dl). Ibrahim et al. (1993) explained that the reduction in TL during hot summer season might be attributed to high ambient temperature, which depresses the rate of thyroid gland secretion. Abdel-Samee et al. (1996) added that decreasing TL in summer in Friesian cows may be due to the metabolism of fat, protein, carbohydrate, minerals and vitamins that disturbed under heat stress conditions due to depression in both appetite and feed intake.

The results of glucose there was significant $(P<0.01)$ seasonal differences between the three seasons. Summer season had lower values of glucose concentrations $(36.51 \mathrm{mg} / \mathrm{dl})$ compared with winter $(57.33 \mathrm{mg} / \mathrm{dl})$ and spring (59.46 $\mathrm{mg} / \mathrm{dl}$ ) seasons. The results revealed that the high AT in summer had a suppressive effect on glucose concentration. Glucose concentration has negative correlation coefficient with AT $(-0.20)$. This result is in agreement with the results of Shaffer et al. (1981), Kobeisy (1996) and Sayah (2005). Shaffer et al. (1981) interpreted the highly significant effect of hot temperature in reaching blood glucose of cattle, as result of increasing respiration rate, which causes a rapid utilization of blood glucose by the respiratory muscles resulting in a decreased blood glucose content $(44.93 \mathrm{mg} / \mathrm{dl})$ under heat stress. Kobeisy (1996) attributed the high level of blood glucose in winter to the effect of cool ambient temperature and the hormonal actions under cold conditions.

The results of thyroxine hormone $\left(\mathrm{T}_{4}\right)$ showed that there were high significant seasonal 
differences between the three seasons $(\mathrm{P}<0.01)$. Summer season had lower values of T4 (2.27 $\mu \mathrm{g} / \mathrm{dl})$ compared with winter $(3.04 \mu \mathrm{g} / \mathrm{dl})$ and spring (3.34 $\mu \mathrm{g} / \mathrm{dl})$ seasons. The results revealed that the high AT in summer had a suppressive effect on $\mathrm{T}_{4}$. Thyroxine hormone concentration has negative correlation coefficient with AT (-0.35). This result is in agreement with the results of El-Masry and Habeeb (1989), Ashour et al. (2000) and Sayah (2005).Yousef and Johnson (1966) suggested that reduction in feed intake due to higher environmental temperatures causes depression in many physiological reactions including thyroid activity which is reduced in cows consuming the same amount of feed at high temperatures $\left(30{ }^{\circ} \mathrm{C}\right.$ and $35{ }^{\circ} \mathrm{C}$ ) as they did at $18{ }^{\circ} \mathrm{C}$ thermoneutral temperature. El-Masry and Habeeb (1989) added that the decrease in thyroid hormones levels during summer might be attributed to the decrease in thyroid stimulating hormone and glucocorticoid hormone. Scott et al. (1983) reported a negative relationship between plasma thyroxine concentration and rectal temperature but the initiation of night cooling at the time when rectal temperature reached the highest value was most beneficial in maintaining thermoneutral plasma thyroxine concentration, he suggested that strategically cooling the heat stressed cow could enhance her metabolic potential. On the other hand, Mohamed (1984) reported that there was a significant increase in $\mathrm{T}_{4}$ in pregnant cows exposed to $30{ }^{\circ} \mathrm{C}$ than animals exposed to $20{ }^{\circ} \mathrm{C}$, the same result was obtained by Collier et al. (1982).

\subsubsection{Body reactions}

The results of RT and RR in Table 4 showed significant $(P<0.01)$ differences between the two housing systems during the three seasons. The loose animals had higher values of RT and RR than restricted animals; these results indicated that the continuous movements of the loose animals especially under hot weather may increase the core temperature, which resulted in increasing the physiological parameters. El-Nouty (1996) found that thermal stress causes a rise in core temperature and activate heat loss mechanism via panting and sweating. The respiration rate was found to be the most sensitive physiological response to the environmental conditions than other physiological responses. Kundu and Bhatnagar (1980) reported that the RR plays an important role in thermoregulatory mechanism amongst all the physiological reactions and body temperature comes next. As for ST, the results of the two housing systems showed insignificant differences. However, the tie-stall animals had higher values than loose animals, this may due to the restricted animals are more affected to housing radiation and convection than loose animals. The results showed also significant seasonal differences $(P<0.01)$ between the three seasons for RT, ST and RR, there are positive correlation coefficients between the three physiological parameters and AT $(0.37,0.86$ and 0.65 , respectively). The average RT, ST and RR of Friesian calves were significantly higher in summer season than in winter and spring. Similar results were obtained by Kandeal (2003). Abdel-Samee et al. (1996) found that RR of Friesian cows in summer increased by about 247 $\%(P<0.01)$ than those of winter. Shafie and ElSheikh Aly (1970) reported that there is a seasonal variation of Friesian body temperature. They reported that the increase in body reaction in Friesian cattle is the result of both gradual rise in atmospheric temperature and the variable increase in body activities of the animal. 
Table 2. Means \pm S.E of Live body weight (LBW, kg), body weight gain (BWG, kg) and daily weight gain (DWG, kg), and their averages for young Friesian bulls kept in two different housing systems.

\begin{tabular}{|c|c|c|c|c|}
\hline \multirow{2}{*}{ Item/Housing types } & \multicolumn{3}{|c|}{ Seasons } & \multirow[b]{2}{*}{ Overall } \\
\hline & Winter & Spring & Summer & \\
\hline \multicolumn{5}{|l|}{$\overline{\mathrm{LBW}}(\mathrm{kg})$} \\
\hline Tie-Stall & $195.17 \pm 7.7^{\mathrm{a}}$ & $305.58 \pm 8.2^{\mathrm{a}}$ & $412.33 \pm 8.5^{\mathrm{a}}$ & $304.36 \pm 8.1^{\mathrm{a}}$ \\
\hline Loose & $185.17 \pm 7.7^{\mathrm{a}}$ & $277.87 \pm 8.2^{\mathrm{b}}$ & $370.29 \pm 8.5^{b}$ & $277.78 \pm 7.8^{b}$ \\
\hline Overall & $190.17 \pm 5.4^{\mathrm{C}}$ & $291.73 \pm 5.8^{\mathrm{B}}$ & $391.31 \pm 6.0^{\mathrm{A}}$ & \\
\hline \multicolumn{5}{|l|}{ MBW (kg) } \\
\hline Tie-Stall system & $52.04 \pm 1.6^{\mathrm{a}}$ & $72.96 \pm 1.5^{\mathrm{a}}$ & $91.40 \pm 1.4^{\mathrm{a}}$ & $72.13 \pm 1.5^{\mathrm{a}}$ \\
\hline Loose system & $50.03 \pm 1.6^{\mathrm{a}}$ & $67.95 \pm 1.5^{b}$ & $84.33 \pm 1.4^{b}$ & $67.44 \pm 1.5^{b}$ \\
\hline Overall & $51.04 \pm 1.1^{\mathrm{C}}$ & $70.46 \pm 1.1^{\mathrm{B}}$ & $87.86 \pm 1.0^{\mathrm{A}}$ & \\
\hline \multicolumn{5}{|l|}{ BWG (kg) } \\
\hline Tie-Stall & $72.25 \pm 3.6^{\mathrm{a}}$ & $110.42 \pm 4.2^{\mathrm{a}}$ & $106.47 \pm 4.1^{\mathrm{a}}$ & $96.38 \pm 4.0^{\mathrm{a}}$ \\
\hline Loose & $62.12 \pm 3.6^{\mathrm{b}}$ & $92.71 \pm 4.2^{b}$ & $92.14 \pm 4.1^{b}$ & $82.32 \pm 4.0^{\mathrm{b}}$ \\
\hline Overall & $67.21 \pm 2.5^{\mathrm{B}}$ & $101.63 \pm 3.3^{\mathrm{A}}$ & $99.65 \pm 3.1^{\mathrm{A}}$ & \\
\hline \multicolumn{5}{|l|}{ DWG (kg) } \\
\hline Tie-Stall & $0.87 \pm 0.0^{\mathrm{a}}$ & $1.22 \pm 0.0^{\mathrm{a}}$ & $0.98 \pm 0.1^{\mathrm{a}}$ & $1.02 \pm 0.03^{\mathrm{a}}$ \\
\hline Loose & $0.75 \pm 0.0^{\mathrm{b}}$ & $1.00 \pm 0.0^{\mathrm{b}}$ & $0.96 \pm 0.1^{\mathrm{a}}$ & $0.90 \pm 0.03^{b}$ \\
\hline Overall & $0.81 \pm 0.0^{\mathrm{B}}$ & $1.12 \pm 0.0^{\mathrm{A}}$ & $0.92 \pm 0.1^{\mathrm{B}}$ & \\
\hline
\end{tabular}

${ }^{\mathrm{a}, \mathrm{b}}$ Means of housing system within each season with different superscripts differ $(P<0.01)$

Table 3. Means \pm S.E. of blood composition concentrations for young Friesian bulls kept in two different housing systems.

\begin{tabular}{|c|c|c|c|c|}
\hline \multirow{2}{*}{ Item/Housing types } & \multicolumn{3}{|c|}{ Seasons } & \multirow{2}{*}{ Overall } \\
\hline & Winter & Spring & Summer & \\
\hline \multicolumn{5}{|l|}{$T P(g / d l)$} \\
\hline Tie-Stall & $8.47 \pm 0.8^{\mathrm{a}}$ & $7.96 \pm 0.5^{\mathrm{a}}$ & $7.48 \pm 0.6^{\mathrm{a}}$ & $7.80 \pm 0.63^{a}$ \\
\hline Loose & $8.21 \pm 0.8^{\mathrm{a}}$ & $9.07 \pm 0.5^{\mathrm{a}}$ & $7.24 \pm 0.6^{\mathrm{a}}$ & $8.17 \pm 0.63^{a}$ \\
\hline Overall & $8.34 \pm 0.6$ & $8.52 \pm 0.5$ & $7.36 \pm 0.4$ & \\
\hline \multicolumn{5}{|l|}{ Albumin $(\mathrm{g} / \mathrm{dl})$} \\
\hline Tie-Stall & $4.10 \pm 0.3^{\mathrm{a}}$ & $4.51 \pm 0.8^{\mathrm{a}}$ & $4.08 \pm 0.3^{\mathrm{a}}$ & $4.23 \pm 0.47^{\mathrm{a}}$ \\
\hline Loose & $4.12 \pm 0.3^{\mathrm{a}}$ & $4.02 \pm 0.8^{\mathrm{a}}$ & $4.11 \pm 0.3^{\mathrm{a}}$ & $4.08 \pm 0.47^{\mathrm{a}}$ \\
\hline Overall & $4.11 \pm 0.2$ & $4.26 \pm 0.3$ & $4.10 \pm 0.2$ & \\
\hline \multicolumn{5}{|l|}{ Globulin $(\mathrm{g} / \mathrm{dl})$} \\
\hline Tie-Stall & $4.37 \pm 0.8^{\mathrm{a}}$ & $3.46 \pm 0.8^{\mathrm{a}}$ & $3.40 \pm 0.7^{\mathrm{a}}$ & $3.74 \pm 0.77^{\mathrm{a}}$ \\
\hline Loose & $4.09 \pm 0.8^{\mathrm{a}}$ & $5.06 \pm 0.8^{\mathrm{a}}$ & $3.13 \pm 0.7^{\mathrm{a}}$ & $4.09 \pm 0.77^{\mathrm{a}}$ \\
\hline Overall & $4.23 \pm 0.5$ & $4.28 \pm 0.6$ & $3.26 \pm 0.5$ & \\
\hline \multicolumn{5}{|l|}{$T L(g / L)$} \\
\hline Tie-Stall & $2.85 \pm 0.3^{\mathrm{a}}$ & $3.65 \pm 0.4^{\mathrm{a}}$ & $3.45 \pm 0.4^{\mathrm{a}}$ & $3.32 \pm 0.37^{\mathrm{a}}$ \\
\hline Loose & $2.79 \pm 0.3^{\mathrm{a}}$ & $2.93 \pm 0.4^{\mathrm{a}}$ & $3.16 \pm 0.4^{\mathrm{a}}$ & $3.96 \pm 0.37^{\mathrm{a}}$ \\
\hline Overall & $2.82 \pm 0.2$ & $3.29 \pm 0.3$ & $3.31 \pm 0.2$ & \\
\hline \multicolumn{5}{|l|}{ Glucose (mg/dl) } \\
\hline Tie-Stall & $56.25 \pm 3.7^{\mathrm{a}}$ & $61.93 \pm 3.2^{\mathrm{a}}$ & $35.76 \pm 4.7^{\mathrm{a}}$ & $51.31 \pm 3.87^{\mathrm{a}}$ \\
\hline Loose & $58.41 \pm 3.7^{\mathrm{a}}$ & $56.99 \pm 3.2^{\mathrm{a}}$ & $37.25 \pm 4.7^{\mathrm{a}}$ & $50.88 \pm 3.87^{\mathrm{a}}$ \\
\hline Overall & $57.33 \pm 2.6^{\mathrm{A}}$ & $59.46 \pm 2.3^{\mathrm{A}}$ & $36.51 \pm 2.7^{\mathrm{B}}$ & \\
\hline \multicolumn{5}{|l|}{$T_{4}(\mu g / d l)$} \\
\hline Tie-Stall & $2.95 \pm 0.3^{\mathrm{a}}$ & $3.71 \pm 0.4^{\mathrm{a}}$ & $2.23 \pm 0.5^{\mathrm{a}}$ & $2.96 \pm 0.40^{\mathrm{a}}$ \\
\hline Loose & $3.13 \pm 0.3^{\mathrm{a}}$ & $2.96 \pm 0.4^{\mathrm{a}}$ & $2.34 \pm 0.5^{\mathrm{a}}$ & $2.81 \pm 0.40^{\mathrm{a}}$ \\
\hline Overall & $3.04 \pm 0.2^{\mathrm{AB}}$ & $3.34 \pm 0.3^{\mathrm{A}}$ & $2.27 \pm 0.3^{\mathrm{B}}$ & \\
\hline
\end{tabular}

$\overline{\mathrm{a}, \mathrm{b}}$ Means of housing system within each season with different superscripts differ $(P<0.01)$

A,B,C Overall means of seasons with different superscripts differ $(P<0.01)$ 
Table 4. Means \pm S.E. of seasonal rectal temperature $\left(\mathrm{RT},{ }^{\circ} \mathrm{C}\right)$, skin temperature $\left(\mathrm{ST},{ }^{\circ} \mathrm{C}\right)$ and respiration rate (resp./min.) for young Friesian bulls kept in two different housing systems.

\begin{tabular}{|c|c|c|c|c|}
\hline \multirow{2}{*}{ type $^{\text {Item/Housing }}$} & \multicolumn{3}{|c|}{ Season } & \multirow{2}{*}{ Overall } \\
\hline & Winter & Spring & Summer & \\
\hline \multicolumn{5}{|l|}{$\overline{\mathrm{RT}}\left({ }^{\circ} \mathrm{C}\right)$} \\
\hline Tie-Stall & $38.46 \pm 0.1^{\mathrm{b}}$ & $38.64 \pm 0.1^{\mathrm{b}}$ & $38.84 \pm 0.1^{\mathrm{b}}$ & $38.65 \pm 0.1^{b}$ \\
\hline Loose & $38.74 \pm 0.1^{\mathrm{a}}$ & $38.80 \pm 0.1^{\mathrm{a}}$ & $39.18 \pm 0.1^{\mathrm{a}}$ & $38.91 \pm 0.1^{\mathrm{a}}$ \\
\hline Overall & $38.60 \pm 0.1^{\mathrm{C}}$ & $38.72 \pm 0.1^{\mathrm{B}}$ & $39.01 \pm 0.1^{\mathrm{A}}$ & \\
\hline \multicolumn{5}{|l|}{$\mathrm{ST}\left({ }^{\mathrm{o}} \mathrm{C}\right)$} \\
\hline Tie-Stall & $29.25 \pm 0.2^{\mathrm{a}}$ & $32.04 \pm 0.4^{\mathrm{a}}$ & $34.62 \pm 0.2^{\mathrm{a}}$ & $31.97 \pm 2.6^{\mathrm{a}}$ \\
\hline Loose & $29.23 \pm 0.2^{\mathrm{a}}$ & $31.38 \pm 0.4^{\mathrm{a}}$ & $34.42 \pm 0.2^{\mathrm{a}}$ & $31.68 \pm 2.6^{\mathrm{a}}$ \\
\hline Overall & $29.24 \pm 0.2^{\mathrm{B}}$ & $31.71 \pm 0.2^{\mathrm{A}}$ & $34.52 \pm 0.2^{\mathrm{A}}$ & \\
\hline \multicolumn{5}{|l|}{ RR (resp. /min.) } \\
\hline Tie-Stall & $27.58 \pm 1.5^{b}$ & $39.19 \pm 1.6^{\mathrm{b}}$ & $58.50 \pm 2.3^{b}$ & $41.76 \pm 0.6^{b}$ \\
\hline Loose & $37.86 \pm 1.5^{\mathrm{a}}$ & $46.75 \pm 1.6^{\mathrm{a}}$ & $61.50 \pm 2.3^{\mathrm{a}}$ & $48.70 \pm 0.6^{\mathrm{a}}$ \\
\hline Overall & $32.73 \pm 1.2^{\mathrm{C}}$ & $42.97 \pm 1.2^{\mathrm{B}}$ & $60.00 \pm 1.2^{\mathrm{A}}$ & \\
\hline
\end{tabular}

\section{Conclusions}

According to the results of this study, it could be concluded that keeping animals in tie-stall system inside a fully shaded barn having dry concrete floor with good drainage and well-ventilated area results in better growth performance than loose system under the same environmental conditions. Moreover, the effect of housing systems is limited mainly to growth performance without influencing blood composition of animals.

\section{References}

Abdel-Samee, A. M, Abou-Fandoud, E. L. and El-Gendy, K. M. (1996). The role of probiotics in ameliorating heat load in lactating Friesian during summer under North Sinai conditions. Egyptian J. Anim. Prod. 33: 277 - 286.

Ahmed, H. I. A. (1990). Studies on alleviating thermal stress in imported Friesian cattle under Egyptian environmental conditions. Ph.D. Thesis, Fac. Agric., Zagazig Univ., Egypt.

Ashour, G., El-Nagar, A. S. Yousef, M. M. and Mourad, H. M. (2000). Growth performance and metabolic profile of Egyptian cattle and buffalo calves. Proc. 3rd All Africa Conf. Anim. Agric. and 11th Conf. Egypt. Soc. Anim. Prod., Alexandria, Egypt.

Ashour, G., Omran, F. I., Yousef, M. M. and Shafie, M. M. (2007). Effect of thermal environment on water and feed intakes in relationship with growth of buffalo calves. Egyptian J. Anim. Prod. 44: 25 - 33.

Bianca, W. (1965). Reviews of the progress of dairy science. Section A, Physiology: cattle in a hot environment. $J$. Dairy Res. 32: 291 - 345.

Cardoso, C.C., Peripolli, V. Amador, S.A. Brandão, E.G. Esteves, G.I.F. Sousa, C.M.Z. França, F.G. Gonçalves, M.F.M.S. Barbosa, F.A. Montalvão, T.C. Martins, C.F. Fonseca Neto, A.M. and McManus, C. (2015). Physiological and thermographic response to heat stress in zebu cattle. Livestock Science, 182: 83-92.

Castaneda, C. A., Gaughan, J. B. and Sakaguchi, Y. (2004). Relationships between climatic conditions and the behaviour of feedlot cattle. Proc. Aust. Soc. Anim. Prod. 25: $33-36$.

Chua, B., Coenen, E., Van Delen, J., and Weary, D. M. (2002). Effects of pair versus individual housing on the behavior and performance of dairy calves. J. Dairy Sci. 85: 360 - 264.

Collier, R.J., Beede, D. K., Thatcher, W. W., Israel, I. A., and Wilcoa, C. J. (1982). Influence of environment and its modification on dairy animals health and production. $J$. Dairy Sci. 65: 2213 - 2227.

Daader, A. H., Marai, I. F. M, Habeeb, A. A. M. and Yousef, H. M. (1989). Improvement of growth performance of Friesian calves under Egyptian subtropical conditions. 1. Internal cooling techniques using diuretics and drinking cool water. Proc. of 3rd EgyptianBritish Conf. on Animal, Fish and Poultry Production, Alexandria, Egypt. 2: 595 - 605.

EL-Masry, K. A. and Hebeeb, A. A. (1989). Thyroid function in lactating Friesian cows and water buffaloes 
under winter and summer Egyptian conditions. Proc. of 3rd Egyptian-British Con. on Animal, Fish and Poultry Production, Alexandria, Egypt.

El-Masry, K. A. and Marai, I. F. (1991). Comparison between Friesian and water buffaloes in growth rate, milk production and some blood constituents, during winter and summer conditions of Egypt. Anim. Prod., 53: 38 - 43.

El-Nouty, F. D. (1996). Heat stress and milk production: Means of alleviation. Egyptian J. Anim. Prod., 33. Suppl. (11): 539-552.

Habeeb, A. A., Marai, I. F. M. and Kamal, T. H. (1992). Heat stress. In: Farm Animals and Environment. Phillips and Piggins (Eds.), CAB International, UK.

Ibrahim, A. I., Abdel-Raheem, A. Abdel-Fattah, M. E. Khalid, K. and Kamal, A. (1993). Some blood constituents of camels in relation to seasonal variations. Zagazig Vet. J., 21: 936 - 942.

Kandeal, M. H. H. (2003). Performance of Friesian calves under different managerial conditions. M.Sc. Thesis, Fac. Agric., Zagazig Univ., Egypt.

Kobeisy, M. A. (1996). Physiological responses of water buffaloes to cool ambient temperature and housing practice. Egyptian J. Anim. Prod., 33: 257 - 267.

Kundu, A. K. and Bhatnagar, D. S. (1980). Physiological reactions in different genetic groups of crossbreds during summer. Indian J. Dairy Sci., 33: 403 - 405.

Lawrence, N. G. (1994). Beef cattle housing. In: Livestock Housing. Wathes, C, and Charles, D. (Eds.), CAB international, UK, pp. 339 - 357.

Lee, J. A., Roussel, J. D. and Beatty, J. F. (1976). Effect of temperature-season on bovine adrenal cortical function, blood cell profile and milk production. J. Dairy Sci., 59: $104-108$

Mader, T.L., Davis, M.S. and Brown-Brandl, T. (2006). Environmental factors influencing heat stress in feedlot cattle. J. Anim. Sci., 84: 712 - 719.

Mohamed, A. A. (1984). Some physiological responses of pregnant cows exposed to heat stress. Indian J. Anim. Sci., 54: 1072 - 1074.

Morrison, S. R. (1983). Ruminant heat stress: effect on production and means of alleviation. J. Anim. Sci., 57: $1594-1599$.

Muhamed, Y. B., Hoffman, M. P. and Self, H. L. (1983). Influence of different rations of corn and corn silage, housing systems and seasons on the performance of feedlot steers. J. Anim. Sci., 56: 747 - 754.

Nardone, A., Ronchi, B., Lacetera, N. and Bernabucci, U. (2006). Climatic effects on productive traits in livestock. Veterinary Research Communications, 30: 75 - 81.

NRC (1981). National Research Council. Effect of environment temperature on nutrient requirements of domestic animals. Natl Acad Press. Washington, DC, USA.

Prawl, Z.I., Owens, F. N. and Gill, D. R. (1998). Effects of pen size or housing on performance and carcass characteristics of feedlot steers. Anim. Sci. Res. Report., 83 -88 .

Pusillo, G. M., Hoffman, M. P. and Self, H. L. (1991). Effects of placing cattle on feed at two-month intervals and housing on feedlot performance and carcass grades. $J$. Anim. Sci., 69: 442 - 50.

Sakaguchi, Y. and Gaughan, J. B. (2002). The effect of heat stress on carcass characteristics of beef cattle. Reproductive loss in farm animal during heat stress. In: Proc. 15th Conf. Biometeorol. Aerobiol, pp.114 - 115.

SAS (2002). SAS user's Guide, Statistics, SAS Inst. Inc., Cary, North California, USA.

Sayah, M. S. (2005). Effect of housing conditions on Friesian calves performance. Ph.D. Thesis, Fac. Agric., Cairo Univ., Egypt.

Sayah, M.S., Abu El-Hamd, M. A., El-Diahy, Y. M. and Halawa, A. A. (2015). Effect of different levels of sodium chloride on physiological parameter and production performance in Friesian lactating cows. J. Animal and Poultry Prod., Mansoura Univ., 6 (11): 677-692

Scott, I. M., Johnson, H. D. and Hahn, G. L. (1983). Effect of programmed diurnal temperature cycles on plasma thyroxine level, body temperature, and feed intake of Holstein dairy cows. Int. J. Biometeor., 27: 47 - 62.

Segnalini, M., Bernabucci, U. Vitali, A. Nardone, A. and Lacetera, N. (2013). Temperature humidity index scenarios in the Mediterranean basin. Int. J. Biometeorol, 57: 451-458.

Shaffer, D., Roussel, J. D. and Koonce, K. L. (1981). Effects of age, temperature season and breed on blood characteristics of dairy cattle. J. Dairy Sci., 64:62 - 70.

Shafie, M. M. and Badreldin, A. L. (1962). The role of blood in regulating body heat in bovines. Egyptian J. Anim. Prod., 2: 61 - 76.

Shafie, M. M. and El-Sheikh Aly, L. M. M. (1970). Heat tolerance of Friesian cattle under Egyptian climatic conditions. Egyptian J. Anim. Prod., 10: 99 - 114.

Terosky, T. L., Wilson, L.L. Stull, C. L. and Stricklin, W. R. (1997). Effects of individual housing design and size on special-fed Holstein veal calf growth performance, hematology, and carcass characteristics. J. Anim. Sci., 75: $1697-1703$.

West, J. W. (2003). Effects of heat-stress on production in dairy cattle. J. Dairy Sci., 86: 2131 - 2144.

Yousef, M. K. and Johnson, H. D. (1966). Blood thyroxine degradation rate of cattle as influenced by temperature and feed intake. Life Sci., 42: 1349 - 1363. 
تأثير التباينات الموسمية ونظم الإيواء على النمو ونواتج التمثيل الغذائي بالام والمؤشرات الفسيولوجية لعجول الفريزيان النامية

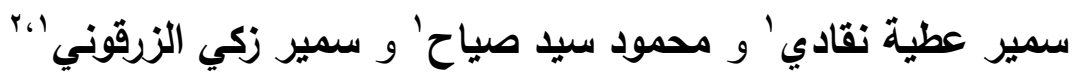

' قسم زراعة المناطق الجافة، كلية الرصاد والبيئة وزراعة المناطق الجافة، جامعة الملك عبد العزيز، المملكة العربية السعودية،

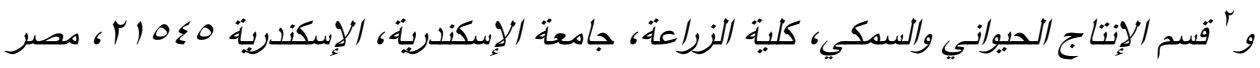
mahmoud_sayah@yahoo.com

المستخلص. استخدم في هذه الدراسة ستة عشر عجل فريزيان بعمر ستة إلى سبعة أشهر لدراسة استجابتهم الفسيولوجية لنظامين مختلفين من الإيواء المربوط والإيواء الحر في فصول فئه الثتاء والربيع والصيف. أظهرت النتائج تقوق نظام الإيواء المربوط على نظام الإيواء الحر الحرئ

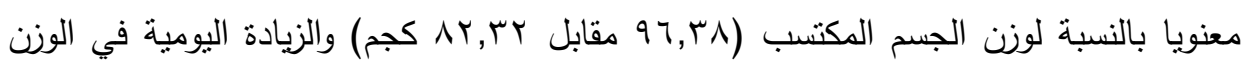

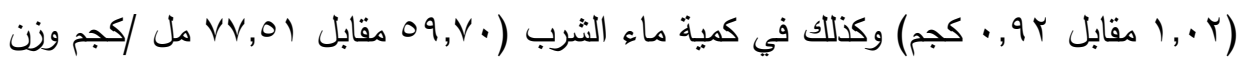

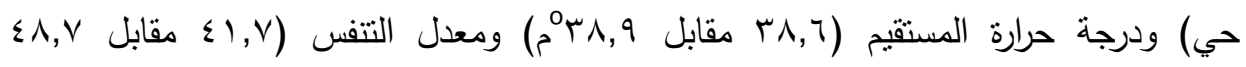
تتفس/دقيقة). بينما لم تظهر اختلافات معنوية بين نظامي الإيواء في كمية الغذاء المأكول

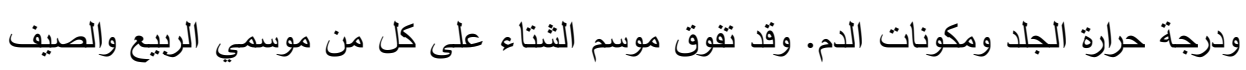

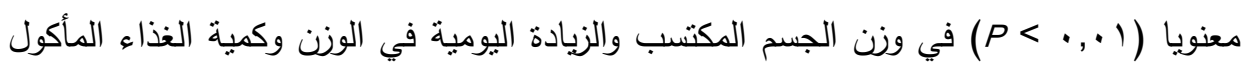
وماء الثرب ودرجة حرارة المستقيم وتركيز هرمون الثيروكسين. كلمات مفتاحية : إيواء مربوط، إيواء حر، فريزيان، النمو، نواتج التمثيل. 
